\title{
Presentation of spatio-temporal data in the context of information capacity and visual suggestiveness
}

\author{
Pawel Cybulski \\ Adam Mickiewicz University in Poznań, \\ Faculty of Geographical and Geological Sciences, \\ Department of Cartography and Geomatics, \\ ul. Dzięgielowa 27, 61-680 Poznań, Poland \\ e-mail: p.cybulski@amu.edu.pl
}

Received: 11 June 2014 / Accepted: 28 September 2014

\begin{abstract}
The aim of this article is to present the concept of information capacity and visual suggestiveness as a map characteristic on the example of two maps of human migration. From this viewpoint the literature study has been performed. Proposed by the author the features of cartographic visualization are an attempt to establish cartographic pragmatics and find the way to increase effectiveness of dynamic maps with large information capacity. Among the works on cartographic pragmatics, muliaspectuality of spatio-temporal data the proposed solution has not been taken so far, and refers to the map design problematic.
\end{abstract}

Keywords: information capacity, visual suggestiveness, multiaspectuality of spatiotemporal data, cartographic pragmatics, map design.

\section{Introduction}

Recently we can observe a considerable development of the methodology of geovisualization. This may be interpreted as the usage of visual representations of spatial information to facilitate thought, improved understanding and the construction of knowledge on aspects of the human environment and the physical environment (Medyńska-Gulij, 2012). In geovisualisation, emphasis is placed primarily on the cognitive nature of the presentation. Of lesser importance in turn is the geographical location, and therefore frequently it is difficult to call contemporary spatial presentations 'maps' in the classic meaning of the term (Faby and Koch, 2010). Thanks to the utilisation of programming languages and advanced graphical software (Dickmann, 2002), the possibilities for creating maps have also undergone considerable change.

The multiaspectuality of spatial data and the omnipresence of statistical databases does not facilitate spatial thought or perception - to the contrary. Such a large set of data may make it difficult to capture even the most obvious relations. A solution for this paradox of geographical visualisation would be so-called explorative data analysis 
or Data Mining (Slocum et al., 2009). This consists in the exploration of immense sets of data in a highly interactive manner, using numerous complex statistical methods. Subsequently, this forms the basis for conclusions as to relations occurring in space. However, this solution is limited to expert users and a very small group of viewers due to the time and knowledge required for analyses of this type. According to some researchers (Roth, 2013; Jovanović, 2012), it is difficult for public user to conclude on the basis of Data Mining analysis. To avoid this author propose identification of spatiotemporal dependences in statistical tables and introduce the idea of information capacity. It is important feature of cartographic visualization introduced to limit the amount of information presented on the map by selecting only most important dependences of studied geographic phenomenon and therefore to prevent perceptual overload.

A public user receives a ready product of explorative data analysis, elaborated by the expert user. Thus, we are faced with the problem of an abundance of spatial information obtained by means of a highly interactive analysis, and the possibilities of effecting the graphical presentation of these phenomena (Kraak and Ormeling, 2010). The actions of the expert user consist in the classification of spatial data from various sources (topographical maps, aerial photographs, field measurements of statistical data, and the integration thereof), the spatial reference, and the identification of the basic spatio-temporal dependences. The next steps concern digitalisation and generalisation until the selection of the digital method of mapping and designing the map, which presents selected features of the phenomenon. The process of passage from the explorative analysis of data until the taking of a decision has been presented in Figure 1.

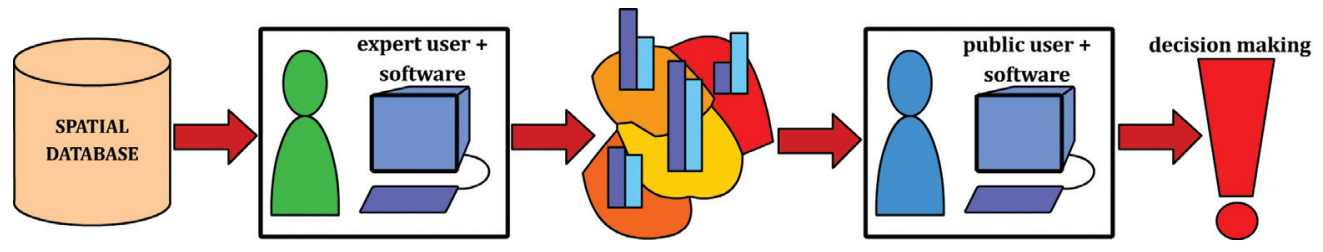

Fig. 1. Process of decision making based on spatial visualization

The visualisation of multiaspectual spatial data is therefore limited to graphical means of presentation. Using visual variables (Bertin, 1983, Morrison, 1974; MacEachren, 1995; Slocum et al., 2009) and dynamic variables applied in cartographic animations (DiBiase, 1992; MacEachren, 1995), one may present the structure of data, their magnitude, and the dynamics of change. However, the presentation of excessively large quantities of data in one study negatively impacts on the decisionmaking process (Bastardi and Shafir, 1998; Haroz and Whitney, 2012). The very big number of spatial information - features or dependences between geographical phenomena - influences the perception of a spatial visualisation. The author has proposed to term this feature of visualisation as "information capacity".

In the visualisation of phenomena that are diverse geographically and over time, a significant role is therefore played by information capacity and the cognitive abilities 
of the viewer. In order to achieve a better effectiveness of cartographic products, one may first and foremost use simple graphical tools, known for centuries (Medyńska-Gulij, 2013), or more advanced (Wielebski and Medyńska-Gulij, 2013; Smith, 2011), or descriptive (Muehlenhaus, 2012) or animated methods (Buckley, 2013; Resch et al., 2013; Fairbairn and Jadidi, 2013). Thanks to the utilisation of the aforementioned means of presentation, the expert user may design a visualisation in such a way as to emphasise selected features of the spatial phenomenon. Information capacity is connected with the number of visual variables, the extensiveness of descriptions and animations, and the combination of methods used to visually strengthen selected features of the spatial phenomenon. Such a process, which enables intuitive perception, may be termed visual suggestiveness.

The aim of the article is to determine the possibilities of visualising multiaspectual spatio-temporal data and their effective presentation in a dynamic approach. In order to properly identify these possibilities, the author presents the concept of information capacity and visual suggestiveness. To sufficiently demonstrate the problem related to these concepts, the author does the literature search for similar issues that are connected with map design. The author also rises the problem of design of maps with a large number of information, and explains the concepts discussed in the article topic. Information capacity and visual suggestiveness are presented on an example of two maps of human migration. Problems connected with each of these features and further explanations are presented in part 2.2 and 2.3. To implement high information capacity and visual suggestiveness in cartographic visualization, the author propose methodological approach.

\section{Methods}

In order to correctly make a map based on statistical data, it is important to use one of the methods used for presentation spatio-temporal statistical data (Olbrich et al., 2002). Author has chosen the human migration phenomenon as an example of a thematic map for presentation idea of information capacity and visual suggestiveness. This phenomenon is commonly presented by method of choropleth map or flow map (Ratajski, 1989).

The structure of this paper includes identification of spatio-temporal dependences in statistical tables in order to limit information capacity (2.1). This step is needed for further empirical studies and is necessary to chose only important statistics. Multiaspectuality of statistical data causes perceptual overload especially in cartographic animations (Cartwright et al., 2007), so author propose this step to organise the statistical data. Author will present the state of research concerning visualisations of multiaspectual spatio-temporal data. In this context we shall propose introducing the feature of information capacity as a criterion for ordering the existing study (2.2). Finally, we shall present the state of research into the perception of these depictions by the public user and propose a visual suggestiveness that favourably impacts the reception of complex spatial visualisations (2.3). 


\subsection{The identification of spatio-temporal dependences in statistical tables}

The phenomenon of the migration of people has been selected for the purpose of theoretical deliberations on information capacity and the visual suggestiveness of a visualization of multiaspectual spatio-temporal data. In addition, since it is economically significant (Domański, 1995), the Main Statistical Office of Poland provides access to very thorough tabular breakdowns of statistical data. The Table 1 shows one of the numerous statistical breakdowns used to show the selected dependences. Their visualisation may uncover still unknown spatial relations. It is easy to see that the quantity of statistical data that is elaborated by statistical offices at the very least necessitates the identification of dependences and an initial analysis of tables. In addition, clarification requires a knowledge of the relations existing between the structure of migrants and their impact on the regional economy (Kuciński, 2009). The process of drawing conclusions on the basis of published data is decidedly laborious and does not facilitate the decision-making process. It is difficult to spatially illustrate numerous features - such as the structure of education, the age structure, or the sex structure - in a single visualisation. For this reason, the first step consists in the identification of dependences in statistical tables, followed by the selection of the appropriate visualisation method.

Table 1 identifies selected dependences and aspects of the phenomenon of migration: the sex structure, spatial structure, time structure, and the reasons for changing one's place of residence. In this instance, the sex structure covers the division into women and men arriving in Poland and is marked using the following colours: blue - men, yellow - women. The spatial structure concerns the division into cities (marked with a dotted line) and villages (marked with a solid line). The time structure is indicated by means of polygons and is divided into immigrants residing in Poland for up to 3 months, from 3 to 12 months, and for more than 12 months. A red frame has been used to designate a single selected reason for changing one's place of residence - treatment and rehabilitation. Arrows identify dependences between the four structures. The process of identification of dependences is an element of the work performed by the expert user in the decision-making process marked in Figure 1. Identification is also necessary for the further visualisation of these dependences, which are presented in further figures.

Research performed so far (Opach and Nossum, 2011; Fish et at., 2011; Haroz and Whitney, 2012) has not made it possible to determine the following: how the multiaspectuality of spatio-temporal data impacts the perception of geographical phenomena and the drawing of conclusions. For this reason, the author of the present deliberations has proposed to consider the effectiveness of cartographic studies devoted to the migration of people in terms of their information capacity. 
Table 1. Identification of spatial and temporal relationships between number of immigrants coming to Poland (Main Statistical Office in Poland)

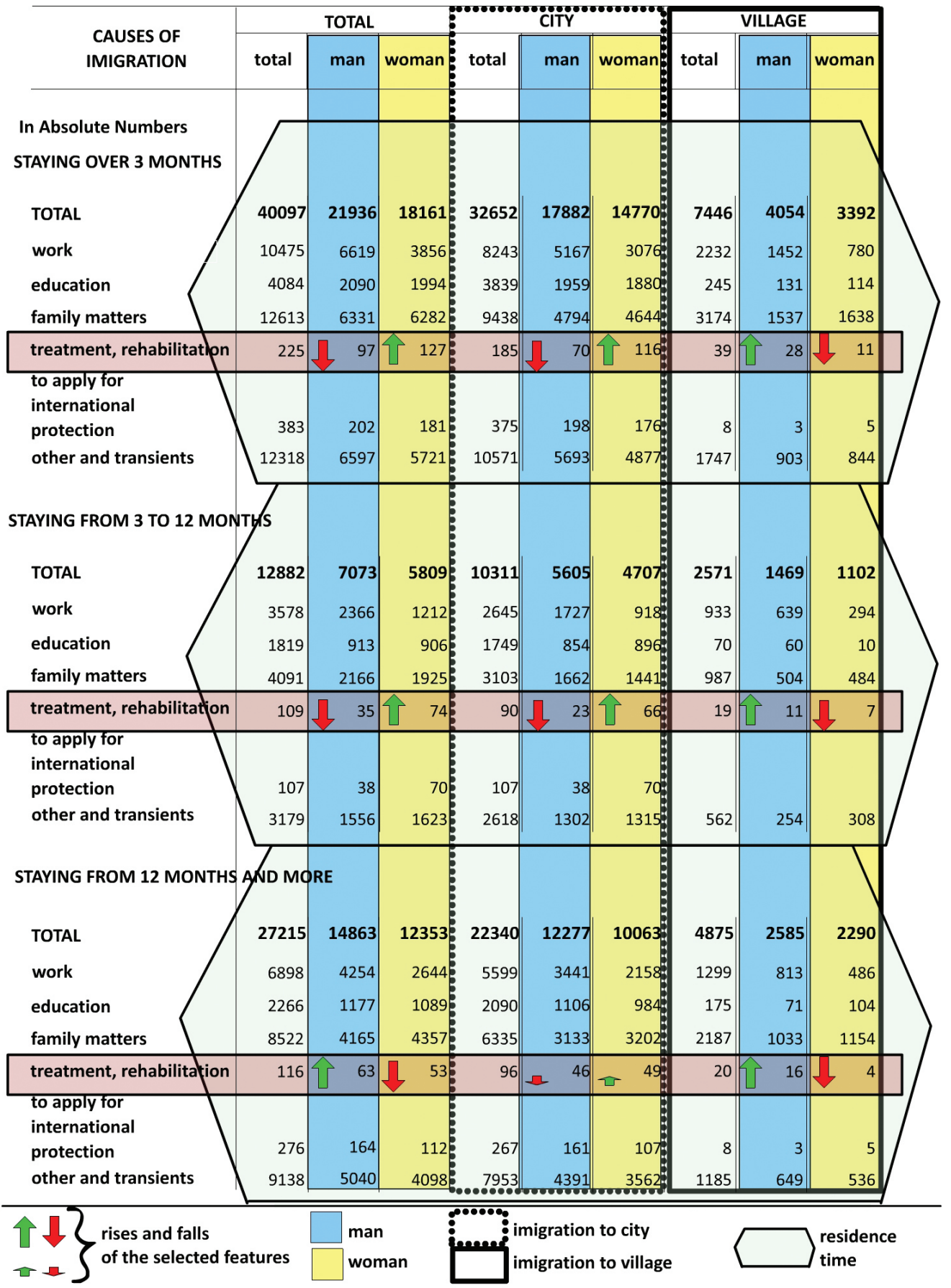




\subsection{Information capacity in cartographic visualization}

Maps concerning geographical phenomena are limited to the presentation thereof by means of visual variables and dynamic variables (MacEachren, 1995; Ratajski, 1989). In consequence of this limitation, a spatial visualisation cannot contain all of the statistical data concerning the migration of people that is present in the study authored by the Main Statistical Office. It is therefore necessary to use additional solution, which does not make it any easier for the public user to draw conclusions and perform an analysis (Cybulski, 2013). Thus, each spatial visualisation has a feature that may be defined as information capacity. The greater the information capacity, the more data one can present using a single visualisation. Since the features of objects are differentiated by means of visual variables (Medyńska-Gulij, 2012) and dynamic variables (DiBiase et at., 1992), information capacity increases along with the number of variables used, irrespective of their remaining parameters. Information capacity is the number of information, features, attributes, or relationships that are shown on a map with visual variables, dynamic variables, or by using unclassified graphic elements. Information can be also expressed through text, sound and pictures. Number of information contained on a map is a subjective choice of map designer. However, the information capacity should be adapted to the perceptive abilities of map recipient. Perception of map user and map designer, or person who is working with maps every day and person who uses map from time to time, is different. Information capacity in the context of visual variables has been presented in Figure 3. Graph does not show the simple mathematical relationship between information capacity and visual variables but only the impression that information capacity is growing with the increasing number of visual variables. Perception of different visual variables is not the same, and depend on various factors like angle, length and area of view (Bezerianos and Isenberg, 2012).

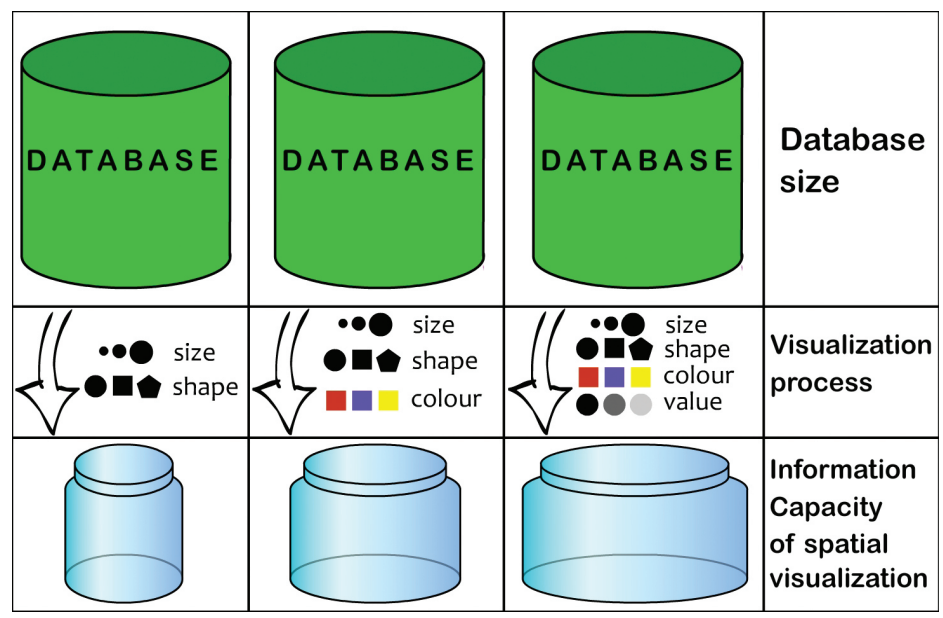

Fig. 2. Idea of Information Capacity of spatial visualization with different number of visual variables 


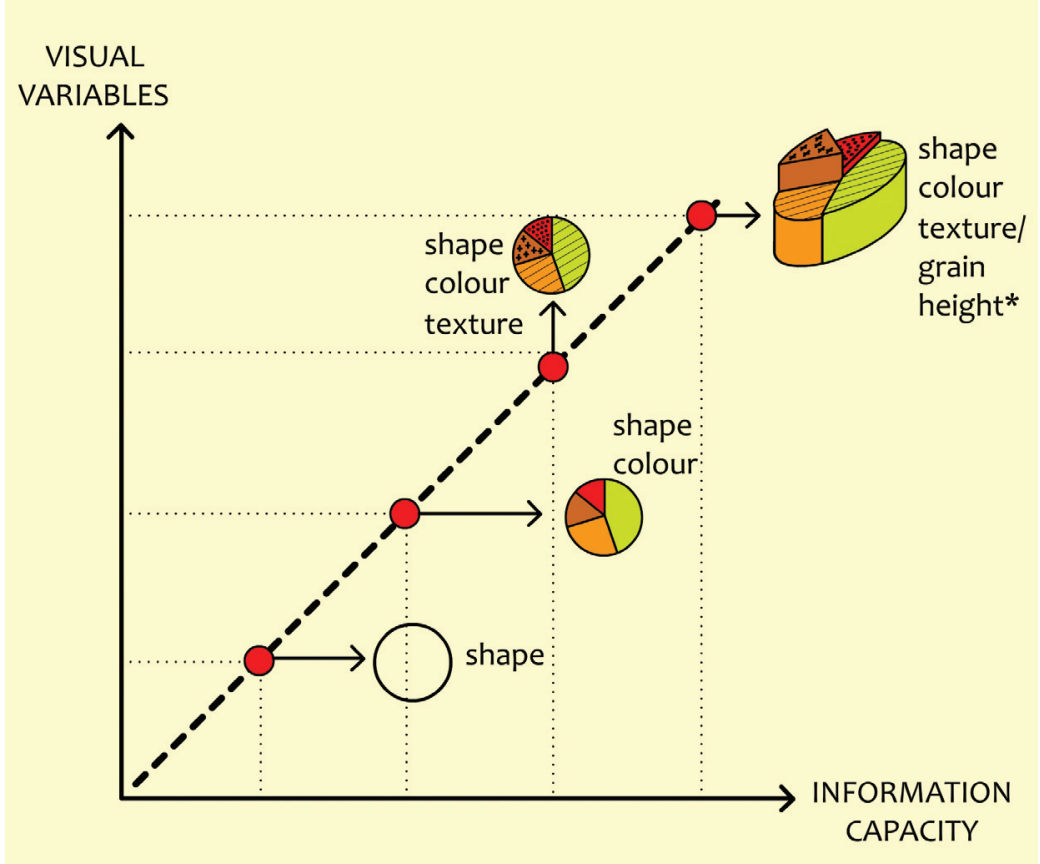

Fig. 3. Information Capacity growth with the growing number of visual variables.

*"Perspective height" is not classical visual variable, it is used in specific causes for choropleth maps and quantitative phenomena (Slocum et al. 2009)

The statistical data concerning the migration of people has been employed as a exemple for presenting the diverse information capacity of maps. Figure 4 is shown only as an example to illustrate the problem that has been considered in this paper and it is not the main base of scientific reasoning. Map A contains considerably less information on the spatial migration of people than map B, which means that its information capacity is lower. It follows that map B has one more visual variables, and the utilisation of colours is more diverse. Thus, it presents information about both emigration from Poland and immigration to Poland. It also shows the reason for changing one's place of residence on the basis of data from the Main Statistical Office and Eurostat. Figure 4 visualises selected dependences of the phenomenon of migration in terms of their varied information capacity. These dependences have been identified similarly as in Table 1, however in this case other reasons for migrating from Poland have been presented. Directions and the provinces from which people arrive have also been shown. In addition, the outflow of people from Poland to selected countries - including the reasons for leaving - has also been presented. Finally, the balance of migration from individual provinces has been visualised. Both emigration and immigration have been presented for people residing outside the borders of their country for in excess of 12 months. 


\section{HUMAN MIGRATION MAP - 2011 (A)}

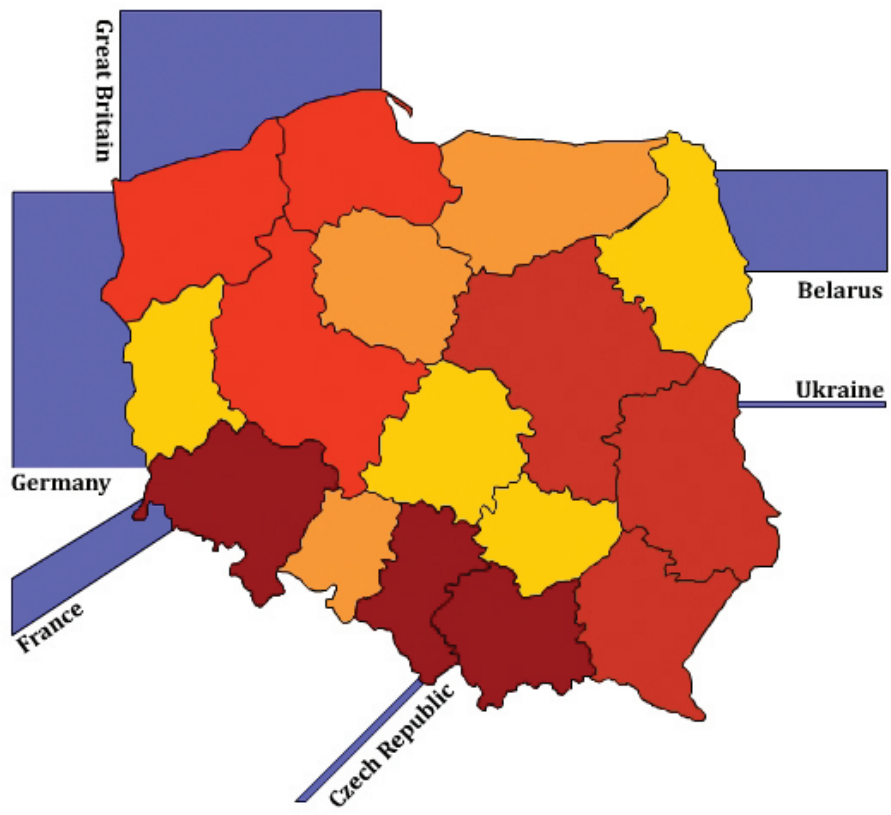

MAP KEY
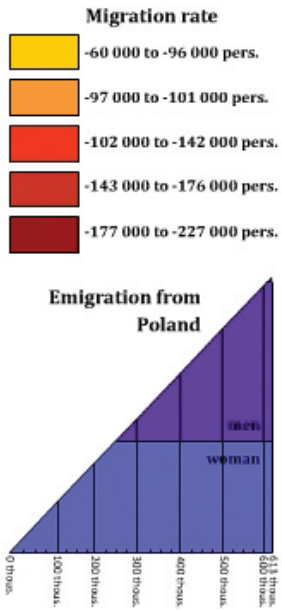

HUMAN MIGRATION MAP - 2011 (B)
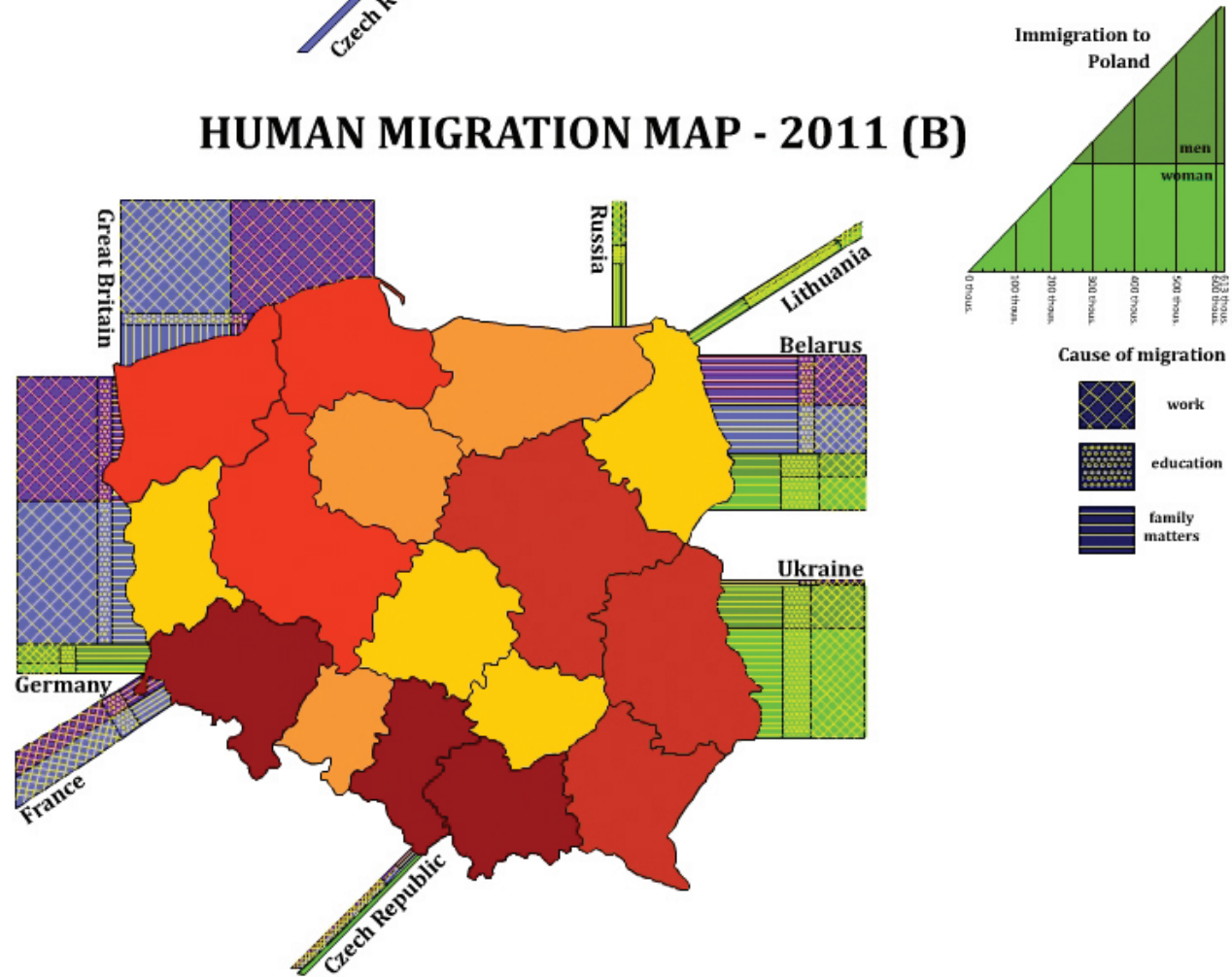

Cause of migration

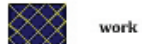

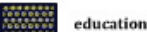

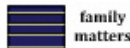

Fig. 4. Different Visual Capacity in Migration Map A and Migration Map B 
The problems are with information capacity are related on one hand with the design of map, but on the other with its perception by the user, which is expressed by cartographic pragmatic. For the map designer problem is a choice of means of expression to include as much spatio-temporal information. Cartographer can of course apply the commonly used methods of mapping, but it is problematic to construct a readable map key. With the data that is changeable in time, such as human migration, a possible solution is temporal legend. One which changes with the content that is displayed on the map. This solution allows to limit the number of items in map key, but from the user point of view, such a solution is not especially preferred due to the fact that that changeable map key is difficult to read.

\subsection{Visual suggestiveness in cartographic visualization}

When designing a spatial visualisation, the expert user selects only those features of a phenomenon that he considers as necessary in the decision-making process. Research carried out to date into dynamic visualisations of geographical phenomena shows that in spite of the fact that only significant features of a phenomenon are presented, the public user has problems with their interpretation (Fish et al., 2011; Popelka et at., 2012; Nossum, 2012). The expert user should therefore design spatial visualisations in such a way as to emphasise those features of the geographical phenomenon that he intends to depict, and also to make it as easy as possible for the viewer to see these features. The author has proposed to call such actions "visual suggestiveness". This expression originates from the word "suggestion", which is defined in the Encyclopaedia Britannica as follows "Process of leading a person to respond uncritically, as in belief or action. The mode of suggestion, while usually verbal, may be visual or may involve any other sense. The suggestion may be symbolic". The adjective "visual", in turn, informs us that the suggestion is not verbal, but rather image-based, using advanced computer graphics and animation solutions. Visual suggestiveness may also be a feature of spatial visualisation. This may be understood as the number of visual variables, descriptions, animations, and the combination of these solutions employed by the author to visually strengthen selected features of the spatial phenomenon.

In the context of cartographic visualisation, suggestiveness may be presented by means of graphics, descriptions, animations, or through a combination of these solutions. The visual suggestiveness of the spatial migration of people in the graphical, descriptive, animated and combined context has been presented in Figure 5. This shows the migration rate, previously presented in Figure 4, however the suggestion serves to emphasise the maximum values of this index. With the help of an additional solution - 3D effect - the graphical suggestiveness emphasises the differences between the balances of migration for three provinces - Greater Poland, Lubuskie and Lower Silesia. By means of an additional description, descriptive suggestiveness distinguishes only the province with the highest migration rate. Animated suggestiveness distinguishes the province of Lower Silesia due to the perceived blinking of its border. 
In turn, combined suggestiveness combines the previously distinguished solutions in such a way as to strengthen not only the differences between the migration rate of provinces, but also to emphasise the maximum value of this migration index. None of the abovementioned solutions of suggestion carries any other information than that presented by means of colour.

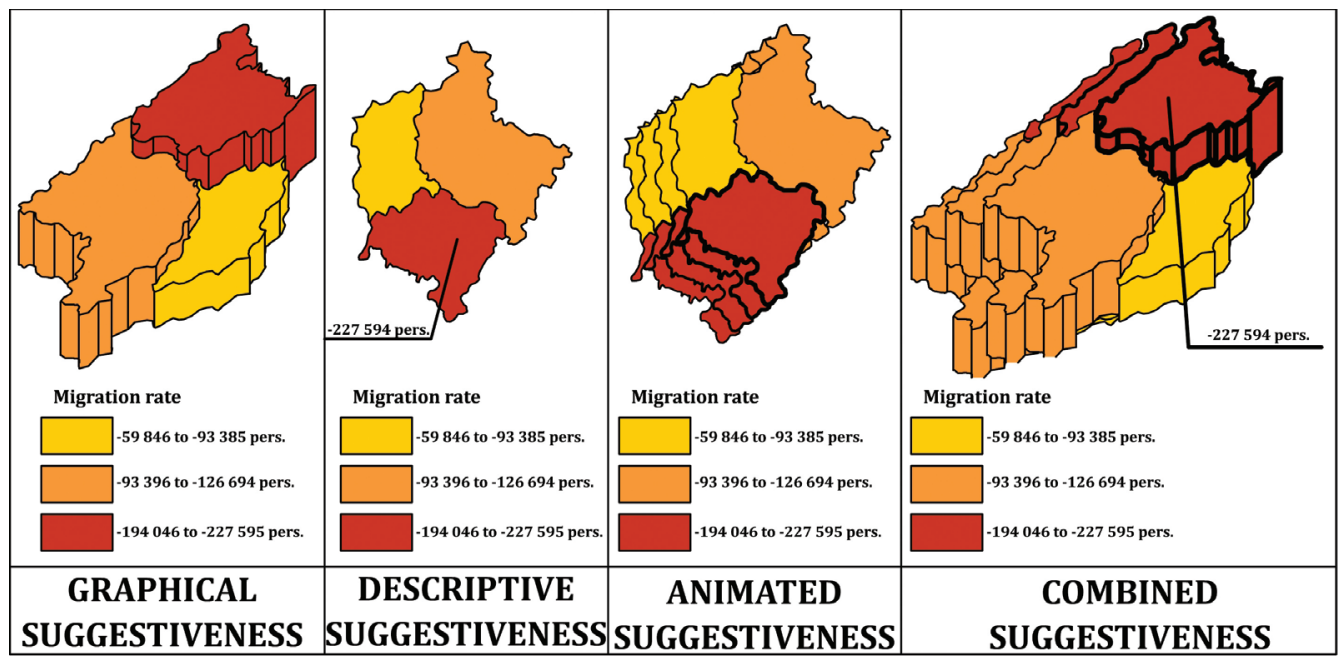

Fig. 5. Different ways of Visual Suggestiveness within spatial visualization

The power of suggestiveness may therefore be determined on the basis of the number of parameters used to emphasise the features of a given geographical phenomenon. In order to consider a given approach as an element of suggestiveness, it cannot carry any additional spatial or temporal information. The remaining features of the visualised phenomenon will develop depending on the feature that the expert user intends to stress.

The problem with the visual suggestiveness involves limited possibilities of emphasizing the features on the maps, which were presented by the methods of mapping. Cartographic methods used to provide information on the map cannot be reused for the suggestion. This problem creates a need to find new methods of mapping. Another problem is the necessity of placing suggestive means in the map key. It is worth considering whether placing suggestive graphics in the map key, which has only aesthetic-stressing character and carries no additional information, should be included. This makes difficult to map user to read the map and map key, which has large information capacity.

Both information capacity and visual suggestiveness may be treated as a process, or as a characteristic of spatial visualisation. The process is understood to mean the creation by the expert user of a visualisation that is informationally capacious and visually suggestive. This consists in the selection of a number of characteristics of a geographical phenomenon, adopting a mapping method therefore, 
and selecting graphical, descriptive, animated or combined solutions. Information capacity and visual suggestiveness may also be interpreted as the characteristic of each visualisation. Information capacity informs us about the number of features of a geographical phenomenon that are presented in a single visualisation. Visual suggestiveness as a feature of visualisation determines the extent to which a given feature of a geographical phenomenon is emphasised.

\section{Conclusions}

The author has presented the two cartographic features such as information capacity and visual suggestiveness. Distinction of these two features of visualization was to determine the possibility of presenting multiaspectual data in dynamic approach. Both concepts refer to the cartographic pragmatics (Medyńska-Gulij 2012). Information capacity is an attempt to comprehend the growing number of data on maps and eliminate redundant information (Bastardi and Shafir, 1998; Haroz and Whitney, 2012). In contrast the visual suggestiveness is the proposal how to present multiaspectual data with effectiveness in communication retained (Muehlenhaus, 2012, Fairbairn and Jadidi, 2013). Therefore, already at the stage of preparing the data, the author proposes to make initial identification and rejection of depending that are not necessary from the designers point of view (Table 1). As an example of problems connected with information capacity and visual suggestiveness, author present human migration maps (Figure 4 and 5).

The problem of the transmission of information with a high information capacity in the case of static and animated maps is an object of many investigation during last 40 years. The concept of visual suggestiveness has been proposed herein as the intentional utilisation of graphical techniques and animation to suitably emphasis the identified features of a geographical phenomenon. The introduction of information capacity makes it possible to order spatial visualisations in terms of their effectiveness and the necessary additional graphical solutions that are intended to improve their effectiveness.

\section{Literature}

Bastardi, A. \& Shafir, E. (1998). On the Pursuit and Misuse of Useless Information. J. of Personality and Social Psychology, 75(1), pp. 19-32.

Bertin, J. (1983). Semiology of Graphics: Diagrams, Networks, Maps. Wisconsin: University of Wisconsin Press.

Bezerianos, A. \& Isenberg, P. (2012). Perception of Visual Variables on Tiled Wall-Sized Display for Information Visualization Applications. IEEE Transactions on Visualization and Computer Graphics, 18,12 , pp. 2516-2525.

Buckley, A. (2013). Guidelines for the Effective Design of Spation-Temporal Maps. Proceedings of the $26^{\text {th }}$ International Cartographic Conference, August 25-30 2013.

Cartwright, W., Peterson, M., \& Gartner, G. (2007). Multimedia Cartography. $2^{\text {nd }}$ Edn, Berlin: Springer. Cybulski, P. (2013). Długość trwania w animacjach czasowych typu frame-by-frame. In: B. Medyńska-Gulij, J. Kubiak (ed) Pragmatyka w kartografii, pp. 31-36. 
Dickmann, F. (2002). Interationserweiterung von Web-Karten mit Hilfe von Skriptsprachen -Das Beispiel JavaScript. In: Kartographische Nachrischten, 1, 19-26.

DiBiase, D. MacEachren, A.M. Krygier, J.B. \& Reeves, C. (1992). Animation and the Role of Map Design in Scientific Visualization. J. Cartography and Geographic Information Systems, 19, Vol. 4, pp. 201-214.

Domański, R. (1995). Zasady geografii społeczno-ekonomicznej. Warszawa: PWN.

Faby, H. \& Koch, A. (2010). From maps to neo-cartography. In: T. Bandrova \& M. Konečny (ed), Proceedings of the $3^{\text {rd }}$ Interational Conference on Cartography \& GIS, (pp. 6). June 15-20 2010.

Fairbairn, D. \& Jadidi, M.N. (2013). Influential Visual Design Parameters on TV Weather Maps. The Cartographic Journal, 50(4), pp. 311-323.

Fish, C. Goldsberry, K.P. \& Battersby, S. (2011). Change blindness in animated choropleth maps: an empirical study. Cartography and Geographic Information Science, 38(4), pp. 350-362.

Haroz, S. \& Whitney, D. (2012). How Capacity Limits of Attention Influence Information Visualization Effectiveness. IEEE Trans. Vis. Comput. Graph., 18(12), pp. 2402-2410.

Jovanovic, J. (2012). Cartographic Visualization and Information Society. Географски разгледи. 46, pp. 59-68.

Kraak, M.J. \& Ormeling, F. (2010). Cartography: Visualization of Geospatial Data. $3^{\text {rd }}$ Edn, Edinburgh: Pearson Education Limited.

Kuciński, K. (2009). Geografia ekonomiczna. Warszawa: Wolters Kluwer Polska.

MacEachren, A.M. (1995). How Maps Works: Representation, Visualization and Design. New York: Guildford Press.

Medyńska-Gulij, B. (2013). How the Black Line, Dash and Dot Created the Rules of Cartographic Design 400 Years Ago. The Cartographic Journal, 50(4), pp. 356-368.

Medyńska-Gulij, B. (2012). Kartografia i geowizualizacja, Warszawa: PWN.

Morrison, J.L. (1974). A theoretical framework for cartographic generalization with the emphasis on the process of symbolization. International Yearbook of Cartography, 14, pp. 115-127.

Muehlenhaus, I. (2012). If Looks Could Kill: The Impact of Different Rhetorical Styles on Persuasive Geocommunication. The Cartographic Journal, 49(4), pp. 361-375.

Nossum, A.S. (2012). Semistatic Animation - Integrating Past, Present and Future in Map Animations. The Cartographic Journal, 49(1), pp. 43-54.

Olbrich, G., Quick, M. \& Schweikart, J. (2002). Desktop Mapping: Grundlagen und Praxis in Kartographie und GIS: mit 153 Abbildungen und 25 Tabellen, Berlin: Springer.

Opach, T. \& Nossum, A.S. (2011). Evaluating the usability of cartographic animations with eyemovement analysis. Proceeding of the $25^{\text {th }}$ International Cartographic Conference, (pp. 1-11), July 3-8, 2011.

Popelka, S. Brychtova, A. Brus, J. \& Voženílek, V. (2012). Advanced Map Optimalization Based on Eye-Tracking. In: C. Bateira (ed) Earth and Planetary Sciences: Cartography - A Tool for Spatial Analysis, pp. 99-118.

Ratajski, L. (1989). Metodyka kartografii społeczno-gospodarczej. $2^{\text {nd }}$ Edn, Warszawa-Wrocław: Państwowe Przedsiębiorstwo Wydawnictw Kartograficznych im. Eugeniusza Romera.

Resch, B. Hillen, F. Reimer, A. \& Spitzer, W. (2013). Towards 4D Cartography - Four-dimensional Dynamic Maps for Understanding Spatio-temporal Correlations in Lightning Events. The Cartographic Journal, 50(3), pp. 266-275.

Roth, R. (2013). Interactive maps: What we know and what we need to know. J. of Spatial Information Science. 6, pp. 59-115.

Slocum, T.A. McMaser, R.B. Kessler F.C. \& Howard H.H. (2009). Thematic Cartography and Geovisualization. $3^{\text {rd }}$ Edn, London: Pearson Education LTD.

Smith, J. (2011). Effective Color Schemes for 3D Animations of Urban Landscapes with a Spatial and Temporal Dimension. Proceedings of the 25th International Cartographic Conference, July 3-8 2011.

Wielebski, Ł. \& Medyńska-Gulij, B. (2013). Cartographic visualization of fire hydrants accessibility for the purpose of decision making. Geodesy and Cartography. 62, pp. 183-198. 
Prezentacja danych czaso-przestrzennych w kontekście pojemności informacyjnej i sugestywności wizualnej

\section{Pawel Cybulski}

Uniwersytet Adama Mickiewicza w Poznaniu Wydział Geografii i Nauk Geologicznych, Zakład Kartografii i Geomatyki,

ul. Dzięgielowa 27, 61-680 Poznań, Polska

e-mail: p.cybulski@amu.edu.pl

\section{Streszczenie}

Celem rozważań było podsumowanie wiedzy dotyczącej projektowania dynamicznych opracowań przestrzennych oraz ich klasyfikacja ze względu na ilość zmiennych graficznych oraz dynamicznych, które mogą zostać użyte w procesie geowizualizacji. Zróżnicowanie ilości zmiennych graficznych i dynamicznych w przestrzennych wizualizacjach autor proponuje nazywać pojemnością wizualną prezentacji. Autor stawia również hipotezę, że im większą pojemność wizualną stosujemy tym bardziej sugestywne musi być to przestawienie, aby efektywność przekazywania informacji była zachowana. 